Volume 13

Issue 1 Revisiting the Life and Work of Raphaël

Lemkin

Article 19

4-2019

\title{
Film Review: 1945
}

Carolyn Sanzenbacher

University of Southampton

Follow this and additional works at: https://digitalcommons.usf.edu/gsp

\section{Recommended Citation}

Sanzenbacher, Carolyn (2019) "Film Review: 1945," Genocide Studies and Prevention: An International Journal: Vol. 13: Iss. 1: 197-199.

DOI:

https://doi.org/10.5038/1911-9933.13.1.1638

Available at: https://digitalcommons.usf.edu/gsp/vol13/iss1/19

This Film Review is brought to you for free and open access by the Open Access Journals at Digital Commons @ University of South Florida. It has been accepted for inclusion in Genocide Studies and Prevention: An International Journal by an authorized editor of Digital Commons @ University of South Florida. For more information, please contact digitalcommons@usf.edu. 
Film Review: 1945

Carolyn Sanzenbacher

University of Southampton

Southampton, England

1945

Director: Ferenc Török

Hungary, 2017

Reviewed by Carolyn Sanzenbacker

Parkes Institute for the Study of Jewish/Non-Jewish Relations

In the same way that Margaret Bourke-White's arresting black and white stills of Buchenwald called out for the story of evil behind them in May 1945, the eye of the camera in Ferenc Török's black and white film 1945 lingers on powerfully framed captures of European postwar life before drawing closer and closer to the disturbing stories behind them. ${ }^{1}$ Török's setting is Hungary rather than the liberated camps of Germany, and it is August 12, four months and one week after German and pro-fascist Hungarian troops were driven out of the country by the Soviets. The year is made clear as the film opens with the screen-filled numbers, the windows through which a rural Hungarian landscape of trees, fields, and clustered buildings comes into view. As the camera rests and peers, first through the outline of the numbers, then incrementally closer to the lives of the Hungarian Christian residents who had experienced the war as it had just played out, the hidden relations and war-time bonds that hold the postwar village together are brought into focus.

The viewer of 1945 sees through the eye of the probing lens, through lacey curtains, around corners, through openings in gates, doorways, and windows, looking for what might be hidden, and from this perspective every resting pause of Török's directed camera becomes a subject of study. In this unobserved-observer sense, the camera and hence the viewer take on the role of a Törökian-guided bystander who watches the bystanders that watched as Hungarian Jews were disenfranchised and deported in the last years of the war. The deliberate unpeeling of the story through this perspective is the studied result of more than ten years of collaboration between Hungarian director Török and Gábor Szántó, the Jewish Hungarian author of 'The Homecoming', on which the film is based, and co-writer with Török of the expanded script. Along with Hungarian cinematographer Elemér Ragályi, an all Hungarian cast, and a hovering awareness of current postHolocaust research, Török and Szántó use this approach to examine the collective behavior of a country who, although aligned with Nazi Germany, developed the postwar narrative "the Nazis did it."

While true that the Hungarian state resisted German urging to deport its Jews, that 760,000 Hungarian Jews were still alive when Germany invaded Hungary in March 1944, and that under occupation as many as 440,000 Jews were deported to Auschwitz-Birkenau and elsewhere by 9 July, the far more fleshed-out story from scholarship is that the Hungarian state and broad swaths of Hungarian society were not only involved in the deportations but profited from them. As summarized by historian Peter Hayes and substantiated by a long line of European, British, Israeli, and American scholarship, "even though most of the victims died at the hands of Germans, not Hungarians, the thoroughness of this operation...was largely homegrown." ${ }^{2}$ The scheme for concentrating Hungarian Jews in ghettos was based on a Hungarian military plan drawn two years prior to the German occupation, and the post-occupation revision of the plan was a collaborative effort between the Hungarian Ministry of the Interior and Adolf Eichmann. Moreover, as evidenced by multiple micro studies, implementation and enforcement of the plan was "left primarily to

\footnotetext{
${ }^{1}$ Life Magazine, 7 May 1945, 32-37.

${ }^{2}$ Peter Hayes, Why? Explaining the Holocaust (New York: W.W. Norton \& Co., 2017), 232. For the definitive study on the Holocaust in Hungary see Randolph Braham, The Politics of Genocide: the Holocaust in Hungary, Vol. I-II, Third Revised and Updated Edition (New York: Columbia University Press, 2016).
} 
Hungarian civil authorities and the Hungarian Arrow Cross" with very limited help from the Nazi SS. ${ }^{3}$

In one case study, for example, which is representative of many, the mayor of a city of 55,000 was responsible for carrying out the Hungarian ghetto decree in his vicinity, and under his auspices members of primary and secondary school faculties, city tax officials, police, and rural gendarmerie decided together where the ghetto would be located in the city. ${ }^{4}$ The roundup itself was conducted by units composed of the same spheres of ordinary citizenry. Local newspapers reported on the process of ghettoizing Jews as it was carried out, making clear to the public that all personal property over and above that which Jews were allowed to take with them was to be requisitioned and treated as national Hungarian property. The expectation of the public was that it would benefit from those acquisitions. Citizens who had been involved in the roundups of Jews applied for confiscated Jewish property on the grounds that, for two weeks from five in the morning until eight at night, they had performed "not only administrative work but also hard physical labor." ${ }^{5}$ Other groups of Hungarian society who applied for confiscated Jewish property included disabled veterans, journalists, teachers, railway workers, civil defense, the local Red Cross, and Catholic and Calvinist Churches. ${ }^{6}$

The rural aspects of this collective eagerness to share in the material spoils of Hungarian nationalization of Jewish property - which is the focus of 1945 - are critically important because the majority of Hungarian Jews whose deaths were a result of deportation were first taken from Hungary's outlying provinces. Rural Jews were rounded up and transported by local units under the direction of local officials, first to ghettos in larger cities and then to ejection sites within six designated deportation zones. That the roundups were accomplished with such efficiency as to reap the deportation of some 440,000 Hungarian Jews within a fifty-five day period between 15 May and 9 July 1944 is a feat which still astounds.

As an inquest into the historical reality of what lay behind that extraordinary "accomplishment," 1945 explores the thorny question of homecoming, by which is meant the post-Holocaust return of surviving Jews to the European countries from which they were deported.7 Török and Szántó's intention is to refute the collective Hungarian memory of what happened during the war by disembarking two black-hatted Orthodox Jews from an arriving train a few months after the close of the war. Through the directorial use of a series of iconic images, which collectively mount and intensify as the film unfolds, the everyday banality of the destination village is peeled away. ${ }^{8}$ The use of numbers for the film's title is an obvious one, as is the repetitive appearance of trains, smoke, and fire, but one of the most powerfully repeated symbols of reality, which is not so iconically familiar, is taken from the little known facts that local Hungarian owners of horse-drawn carts were hired at fixed daily rates to transport Jews to ghettos and deportation sites, and that thousands of individual cart-owners were involved in the transport process. ${ }^{9}$ Under Török's direction and

\footnotetext{
${ }^{3}$ Ibid., 231-234.

${ }^{4}$ Anders Bloomqvist, "Local Motives for Deporting Jews: Economic Nationalizing in Szatmárnémeti in 1944," The Hungarian Historical Review, 4, no. 3 (2015), 673-704.

${ }^{5}$ Ibid., 690-698.

${ }^{6}$ Ibid. See also Borbála Klacsmann, "Abandoned, Confiscated, and Stolen property: Jewish-Gentile Relations in Hungary as Reflected in Restitution Letters," Holocaust Studies: A Journal of Culture and History, 23, nos. 1-2 (2017), 133-148; Ferenc Laczó, ed., Special Edition: The Holocaust in Hungary in Contexts: New Perspectives and Research Results, The Hungarian Historical Review Jews in the Age of Genocide: An Intellectual History, 1929-1948, 4, no. 3 (2015); Tatjána Tönsmeyer, "The Robbery of Jewish Property in Eastern European States Allied with Nazi Germany," in Robbery and Restitution, ed. Martin Dean (Berghahn Books, 2007), 81-98; Krisztíán Ungváry, "Robbing the Dead: The Hungarian Contribution to the Holocaust," Facing the Nazi Genocide: Non-Jews and Jews in Europe, ed. Beate Kosmala and Feliks Tych (Berlin: Metropol, 2004), 231-261.

${ }^{7}$ David Bankier, ed., The Jews Are Coming Back: The Return of the Jews to Their Countries of Origin After World War II (New York, Jerusalem, 2005). László Karsai, "Shylock is Whetting His Blade": Fear of the Jews' Revenge in Hungary during World War II," in The Jews are Coming Back: The Return of the Jews to Their Countries of Origin after WWII, ed. David Bankier (Jerusalem: Yad Vashem, 2005).

${ }^{8}$ Oren Stier, Holocaust Icons: Symbolizing the Shoah in History and Memory (Rutgers University Press, 2015).
} 
Ragályi's camera, those obscure historical facts are transformed into a centralizing force: starkly framed black and white images of a horse-drawn wagon, transporting two casket-like crates, with two uninvited Jews walking silently behind it.

While the dialogue in 1945 is intentionally spare, with thunderous bursts of words - The Jews are coming, Jews are in the village, Go warn the others - it is by no means a more or less silent film. Like the repetitious images of horse-drawn cart, sealed coffin-like boxes, and the portentous ongoing walking of two Orthodox Jews, repeated iconic sounds are used to move the film along from start to finish. The click klopping of hooves striking a road, the tick tocking of clocks in sundry places, the characteristic rip of dirt from the earth, all of these play atmospheric roles of continuity from the time the Jews arrive until they leave some four hours later. Even the score itself, a sophisticated composition of often discordant notes, makes use of church bells and unoiled machinery to remind that this is a Christian village, and that what happened there in the summer of 1944 was but part of a broader state-mechanized collaboration with Nazi Germany, in which ordinary Hungarian citizens were complicit.

Yet, replete as the film is with fractured dialogue and discordant sounds, it is at times characteristic of a silent film whose melodrama is needed to capture the ways in which human deceit plays out in a conspiracy of silence as it implodes. The spirits of the past are thick and daunting, driving the guilty to measures that otherwise would not have been taken, each of which offers an unsettling juxtaposition to the steady-walking Jews who are on an undeterred religious mission. Stark, lean, uncomfortably clear and grim at times, 1945 offers a needed story about those who were forced to leave, those who stayed, those who return, and those who voluntarily leave, a story more or less ended in ashes, like the lives of some 500,000 Hungarian Jews. The film is an indicting examination of one slice of what happened in Hungary, but it is also a disturbing fictional reflection of what is now a consensus of Holocaust historiography: that the genocide could not have happened without the complicity and passivity of bystanders. The collective village portrait that is brought into bold relief by Török's use of repetitiveness, contrasts, and juxtapositions lays bear all notions of "the Nazis did it" and reveals layer by layer the choices, decisions, and ways in which ordinary Hungarians involved themselves in the destruction process.

Title of the Film: 1945; Director: Ferenc Török; Producers: Iván Angelusz, Péter Reich, Ferenc Török; Screenplay: Gábor Szántó and Ferenc Török; Cinematography: Elemér Ragályi; Film Editor: Béla Barsi; Sound Designer: Tibor Szemző; Country: Hungary; Year of Release: 2017; Production Company: Katapult Film; Duration: 91 minutes.

\footnotetext{
${ }^{9}$ Tim Cole, Traces of the Holocaust: Journeying in and out of the Ghettos (London: Continuum Books, 2011), 28-40. In one rural area alone, more than 1,000 Hungarian cart owners transported Jews to and from ghettos for deportation in the six week period between the end of April and early June, 32 .
} 